oczach. W codziennej egzystencji niezbędnymi narzędziami są internetowe wyszukiwarki Google i Yahoo, programy takie jak You Tube, czy urządzenia dawniej nazywane telefonami, jak iPhone. Tymczasem są one już przedmiotem analiz historycznych. Przeszłość i teraźniejszość w erze społeczeństwa informacyjnego to niemal jedno, a przynajmniej dystans między nimi skurczył się do minimum. Przekonujemy się o tym, oglądając eksponaty w muzeach, które jeszcze używaliśmy kilka, kilkanaście lat temu. Telewizory lampowe, komputery, które zamiast pamięci posiadały magnetofony kasetowe, gry telewizyjne zestarzały się szybciej niż używające ich pokolenie.

Kilka słów wypada poświęcić przeznaczeniu czytelniczemu książki. Ma ona charakter podręcznika akademickiego i w tym kontekście nieco szkoda, że zabrakło merytorycznego komentarza wprowadzającego adresowanego do polskiego czytelnika i ewentualnego uzupełnienia bibliografii o opracowania rodzimych badaczy. W wypadku tej książki ma to uzasadnienie również dlatego, że autorzy niejednokrotnie przytaczali treści dotyczące rozwoju mediów i ich społecznych efektów w Polsce. Z punktu widzenia dydaktycznego doskonałym natomiast ułatwieniem są załączone do pracy kalendarium oraz indeks nazwisk, opatrzony adnotacjami.

Tomasz Kruszewski (Toruń)

\title{
T. Ładoń, Wojna sertoriańska (80-71 przed Chr.), Wydawnictwo Napoleon V, Oświęcim 2011, ss. 182
}

M ożna powiedzieć, że książka Tomasza Ładonia w dużej mierze wypełnia istotną lukę w polskich badaniach nad tytułowym fragmentem dziejów późnej republiki rzymskiej. Sertoriusz, jak wiadomo, był jedną z najbardziej intrygujących postaci ówczesnego świata. Wzbudzał emocje już wśród starożytnych historyków, a nie mniejsze w gronie współczesnych badaczy. Jedni uważali go za bohatera, który chciał uratować Rzym, inni odnosili się do niego nader krytycznie, a część antycznych historyków po prostu wrogo. Ten wywodzący się z nizin społecznych jednooki bohater wojny domowej, którego Plutarch zestawia z Filipem Macedońskim, Antygonosem i Hannibalem (Sert. I, 4), Appian zaś mówi o nim, że Celtyberowie wprost nazywali go Hannibalem $(B C$ 112, 522), miał bardzo ciekawą, ale i skomplikowaną osobowość. 
We wstępie (s. 7-19) autor omawia antyczne źródła odnoszące się do Sertoriusza. Skrupulatnie je wymienia, także te zachowane fragmentarycznie, a przy okazji zwraca uwagę na ich obiektywną wartość, ponieważ niektórzy antyczni autorzy bywali nieobiektywni i zaangażowani w walkę polityczną po jednej ze stron. Następnie przedstawia stan badań nad wojną sertoriańską w literaturze światowej. Ładoń stara się uwzględnić tutaj nie tylko literaturę odnoszącą się bezpośrednio do Sertoriusza i jego działań w Hiszpanii, ale sięga również do tych opracowań, które traktują o jego przeciwnikach, jako że bez znajomości działalności Pompejusza czy Metellusa ocena czynów Sertoriusza byłaby niepełna. Ponadto na tle osiągnięć tych znakomitych wodzów można było lepiej ukazać jego taktyczne zdolności.

Książka została podzielona na dwa rozdziały. W pierwszym z nich (s. 21-51) autor przedstawia początki kariery wojskowej Sertoriusza i jego pierwsze kroki w polityce. Ukazuje działania, które umożliwiły mu prawdziwe zaistnienie na rzymskiej scenie politycznej, a więc wspinanie się po kolejnych szczeblach kariery urzędniczej, udział Sertoriusza w wojnie domowej po stronie Mariusza i Cynny, wyjazd do Hiszpanii oraz pobyt w Afryce. W podsumowaniu tego rozdziału autor stwierdza (s. 50), że „mimo dużych zdolności, którymi wykazał się Sertoriusz w trakcie pierwszego etapu swojej kariery wojskowej, trudno uznać ją za spektakularną", po czym dodaje: „ocena kariery politycznej Sertoriusz wypada jeszcze bardziej blado”, przynajmniej do powrotu do Hiszpanii w 80 roku.

W rozdziale drugim Autor przedstawia kolejne etapy wojny sertoriańskiej, tj. kampanię w Luzytanii (s. 53-60), przygotowania wojskowe i organizacyjne (s. 60-70), wypadki wojenne pod Lauro, Italiką, Segowią, nad rzeką Sucro, w pobliżu Segontii i pod Clunią (s. 71-102) oraz kampanię lat 74-73 (s. 103-105). Następnie omawia kwestie związane ze spiskiem na życie Sertoriusza i jego urzeczywistnieniem (s. 106-118) i kończy ten rozdział uwagami odnoszącymi się do końca wojny sertoriańskiej (s. 118-123).

Krótkie Zakończenie (s. 125-130) jest próbą podsumowania kariery Sertoriusza i ukazania celu jego działalności, który jednak umyka precyzyjnemu określeniu, a przynajmniej przedstawione przez T. Ładonia uwagi i kontrowersje nie dają jednoznaczej odpowiedzi na postawione przezeń pytania.

Należy zaznaczyć, że Ładoń stara się przedstawić wypadki wojenne w sposób zajmujący i zgodny z bardzo nieraz nierówną materią źródłową na ich temat. Pokazuje, jak niełatwo czasem ustalić lokalizację miejsc bitewnych i szczegółowy przebieg danej kampanii, i to nawet wówczas, gdy ma się do dyspozycji dokładniejsze przekazy (por. s. 82, przyp.114 odnoszący się do źródeł związanych z przebiegiem bitwy nad rzeką Sucro). Autor za każdym razem stara się przedstawić sądy badaczy na dany temat, sam zaś opowiada się za, jego zdaniem, najbardziej prawdopodobnymi rekonstrukcjami wypadków. 
Warto podkreślić, że, pisząc o wojnie seroriańskiej, Ładoń nie zajmuje się tylko relacjami z poszczególnych kampanii, ale nie traci z oczu innych wydarzeń, które stanowią dopełnienie i tło działalności politycznej Sertoriusza w Hiszpanii i poza nią. Osobną uwage poświęca zatem utworzeniu na Półwyspie Iberyjskim hiszpańskiego senatu, z rzymskiego punktu widzenia oczywiście „antysenatu”, na którego temat piszą jedynie jedynie Appian i Plutarch, i są to relacje bardzo różne. Kontrowersje dotyczą nie tylko daty powstania owego senatu poza Rzymem, lecz także przyczyn, które do tego doprowadziły. Wprawdzie za jego organizatora uważa się Sertoriusza, ale autor słusznie zwraca uwagę na fakt, że „stosunki między Sertoriuszem, a działającym u jego boku senatem, nie układały się najlepiej [...] zwłaszcza pod koniec rebelii. Na posiedzeniach [...] krytykowano bowiem działania Sertoriusza [...]”, i to właśnie „w kręgach senackich zrodził się [...] spisek na życie Sertoriusza, w którego wyniku wodza zamordowano [...]", s. 69. Jednak ostateczny wniosek, jaki z tej sytuacji wyciąga, jest co najmniej dyskusyjny. Ładoń stwierdza mianowicie, że jeżeli „na kwestię genezy hiszpańskiego senatu popatrzy się w takim kontekście, dziwne może się wydawać uznanie w osobie Sertoriusza inspiratora jego powołania”. Trudno bowiem zgodzić się z tą teza, ponieważ jest rzeczą jasną, że Sertoriusz, powołując senat, nie mógł przewidzieć nie tylko tego, że jego członkowie zajmą wobec niego stanowisko krytyczne, ani też z góry zakładać, że tutaj właśnie zawiąże się spisek na jego życie.

Bardzo ważne miejsce w pracy o Sertoriuszu stanowią także rozważania na temat paktu, jaki zawarł on z Mitrydatesem. Szczegóły tego traktatu i okoliczności jego zawarcia były przedmiotem wielu kontrowersji. Po przedstawieniu dwóch różnych w szczegółach relacji źródłowych (Appiana i Plutarcha), autor rozważa, która z nich bardziej odpowiada wizerunkowi Sertoriusza. Naturalnie już sam fakt pertraktacji z wrogiem może stawiać Sertoriusza w niekorzystnym świetle (na dodatek miał się on chełpić, że jego sława sięgnęła Pontu). Oczywiście w wyniku podjętych rokowań Sertoriusz zyskał „pomoc materialną”, przy czym w oczach Rzymian stał się jeszcze bardziej niebezpieczny (s. 98). W tej części pracy Ładoń wykorzystuje swe wcześniejsze opracowanie na ten temat i wypada podkreślić, że całą tę problematykę i związane z nią polemiki ukazuje w sposób bardzo przejrzysty.

Natomiast szkoda, że pominął zupełnie inny problem, jaki wiąże się z postawą Sertoriusza, a mianowicie kwestię prawnego jego statusu z tą chwilą, kiedy podjął on działania obrócone przeciwko Rzymowi. Chodzi mianowicie o uznanie Sertoriusza za hostis publicus, które po śmierci Sulli nabrało szczególnego wymiaru (na ten temat zob. np. I. König, Q. Sertorius. Ein Kapitel des frühen römischen Bürgerkriegs, „Klio” 82, 2000, s. 452).

Książkę dopełniają użyteczne aneksy (s. 133-138; m.in. kalendarium, wykaz rzymskich namiestników, tabelarycznie zestawione informacje na temat ilości i lo- 
kacji rzymskich legionów) oraz dodatek traktujący o „liczebności oddziałów rzymskich uczestniczących w wojnie sertoriańskiej” (s. 139-150).

Można zatem powiedzieć, że dzięki pracy T. Ładonia otrzymaliśmy rzetelne opracowanie niewielkiego wprawdzie, ale bardzo istotnego fragmentu rzymskiej historii. Jego wartość podnosi jeszcze poprawny aparat naukowy, w którym odsyłacze do źródeł i literatury przedmiotu pozwalają czytelnikowi konfrontować słuszność uwag Ładonia z odnośnym materiałem. Czasami jednak pojawia się odczucie pewnego niedosytu, zwłaszcza tam, gdzie autor stara się referować poglądy współczesnych badaczy i zaistniałą polemikę. Sam autor nie waha się wszakże przedstawiać własnego punktu widzenia, a w ocenie postaci Sertoriusza widać troskę o jak największy obiektywizm.

Wojnę sertoriańską"T. Ładonia z przekonaniem można więc polecić miłośnikom dziejów militarnych, a i osoby zainteresowane polityczną historią późnej republiki rzymskiej odniosą korzyść z jej lektury.

Hanna Appel (Toruń)

\section{Krystyna Bartol,JerzyDanielewicz,Komediagrecka.OdEpicharma do Menandra. Wybór fragmentów, Wydawnictwo Naukowe PWN, Warszawa 2011, ss. 520*}

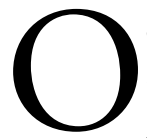

statnia książka profesorów Uniwersytetu im. Adama Mickiewicza Krystyny Bartol oraz Jerzego Danielewicza dotycząca komedii greckiej to kolejna już wspólna praca wybitnych znawców greckiej literatury. W roku 2010 został wydany przekład i komentarz Uczty mędrców, monumentalnego dzieła poklasycznego uczonego i pisarza Atenajosa ${ }^{1}$. Przedmiotem zainteresowania Autorów nie są dzieła, które zachowały się w całości (wykaz ich przekładów na język polski

* Recenzja napisana w ramach projektu „Eastern Mediterranean from the 4th century BC until Late Antiquity” realizowany w ramach programu MPD Fundacji na rzecz Nauki Polskiej, współfinansowanego ze środków Europejskiego Funduszu Rozwoju Regionalnego w ramach Programu Operacyjnego Innowacyjna Gospodarka.

${ }^{1}$ Atenajos, Uczta mędrców, przełożyli, wstępem i komentarzem opatrzyli K. Bartol i J. Danielewicz, Poznań 2010. 